PROCEDIA

Studi Kasus dan Intervensi Psikologi

ISSN:2302-1462; e-ISSN: 2722-7669

Volume 8(2) 55-64, Juni 2020

DOI: $10.22219 /$ procedia.v8i2.13426

\title{
Pelatihan Asertif Pada Narapidana Lapas Malang
}

\author{
Windy Rainata, Universitas Muhammadiyah Malang, Malang, Indonesia
}

Korespondonesi:

Windy Rainata, email: windy.ainata@gmail.com

\section{Riwayat artike \\ Naskah diterima: \\ $05 / 03 / 2020$}

Revisi diterima:

$29 / 03 / 2020$

Naskah disetujui: $10 / 05 / 2020$

\begin{abstract}
Abstrak
Es (laki-laki/32 tahun) tidak mampu untuk mengungkapkan apa yang dirasakan maupun yang dipikirkannya kepada orang lain karena takut akan merepotkan orang lain dan membuat susah orang lain. Perilaku ini memberikan dampak pada kehidupannya dan membawa Es berada di Lapas. Berdasarkan hasil asesmen wawancara, observasi, tes grafis, rathus assertive scale (RAS), dan SPM subjek memiliki hambatan dalam berinteraksi dengan orang lain, pemalu, tidak asertif dalam mengungkapkan perasaannya, tertutup, dan memiliki trauma atau permasalahan di usia mudanya. Latihan asertif bertujuan untuk meningkatkan perilaku asertif subjek sehingga dapat mengungkapkan perasaannya dengan lingkungan disekitar melalui pelatihan asertif sebanyak 5 sesi dengan pendekatan perilaku. Hasil intervensi menunjukkan bahwa subjek mampu mengutarakan apa yang dirasakannya kepada orang lain dan mengungkapkan apa yang dipikirkannya dengan lebih baik. Pelatihan asertif terbukti mampu meningkatkan perilaku asertif subjek dan mengembangkan kemampuan asertifnya.

Kata kunci: pelatihan asertif, pendekatan perilaku, lapas, intervensi
\end{abstract}

\section{Latar Belakang}

Manusia merupakan makhluk sosial yang artinya dalam melangsungkan kehidupannya maka akan melakukan kontak sosial dan membutuhkan bantuan dari orang lain dalam kesehariannya (Anto, Rusdi, 2018). Untuk dapat melakukan kontak sosial tersebut, manusia diajarkan bagaimana berkomunikasi dan menyampaikan maksud dan tujuannya kepada orang lain. Lingkungan berpengaruh dalam proses belajar seseorang yang memberikan penilaian positif dan negatif (Corey, 2003).

Skinner mengungkapkan bahwa perilaku yang dipelajari oleh manusia apabila mendapatkan penguatan akan dipertahankan maupun dihilangkan (Miltenberger, 2004). Beberapa kasus yang terjadi saat ini seringkali diakibatkan oleh ketidakmampuan seseorang dalam 
mengungkapkan emosi ataupun perasaannya secara tepat dan benar. Individu yang mampu mengungkapkan perasaannya akan mudah bergaul dalam lingkungan sosial dan cenderung sedikit mengalami permasalahan, namun berbeda dengan individu yang mengalami kesulitan dalam mengungkapkan perasaannya (Ramdhani, 2015).

Perilaku kesulitan dalam mengungkapkan perasaannya disebut sebagai kurang asertif, hal ini terjadi pada subjek kasus ini. Subjek merupakan individu yang terjerat kasus pencabulan anak dibawah umur (81 KUHP) dan ditahan di Lapas pria Malang. Semua berawal dari ketidakmampuan subjek untuk tegas mengungkapkan masalah. Awalnya subjek bermasalah dengan istrinya karena tidak berani mengungkapkan perasaannya sehingga mencari kenyamanan pada wanita lain yang ternyata tidak disetujui oleh pihak keluarga wanita tersebut. Hal tersebut akhirnya menjadi pemicu permasalahan lain dan keluarga menuntut untuk subjek menyerahkan anak perempuan itu yang tidak bersama dengan dirinya. Namun, subjek merasa bertanggung jawab atas anak tersebut dan menerima apapun yang akan terjadi pada dirinya yang dituntutkan oleh pihak keluarga.

Ketidakmampuan untuk bersikap asertif ini dapat ditingkatkan melalui pelatihan asertif. Pelatihan asertif ini menekankan keterampilan sosial untuk mengungkapkan dengan tegas apa yang dirasakannya tanpa melanggar hak-hak orang lain (Corey, 2003). Pelatihan asertif sebagai salah satu teknik untuk meningkatkan perilaku asertif baik secara verbal maupun non verbal untuk meminimalkan kasus lain yang akan muncul dalam kehidupannya setelah bebas (Hartati, H., Dimyati, M., Herdi, 2017). Subjek mengalami kesulitan untuk bersikap asertif sehingga teknik ini dapat digunakan dengan langkah-langkah yang terdapat dalam latihan asertif.

\section{Metode Asesmen}

Asesmen untuk penegakan diganosa yang tepat dilakukan melalui serangkaian metode antara lain wawancara, observasi dan tes psikologi. Wawancara dilakukan terhadap subjek, teman hunian lapas dan juga keluarga untuk memperoleh informasi lebih mendalam tentang riwayat permasalahan yang subjek alami. Observasi dilakukan untuk pemeriksaan status mental subjek dan untuk memperoleh informasi perilaku dan aktivitas subjek selama di lapas malang.

Tes psikologis yang digunakan tes grafis (BAUM, DAP, HTP) untuk menganalisis kepribadian subjek yang belum terungkap berdasarkan proyeksi gambar masing-masing dan juga tes inteligensi menggunakan Standart Progressive Matrics (SPM) untuk memberikan gambaran kecerdasan subjek. Subjek juga diberikan skala RAS (rathus assertive scale) untuk melihat sejauh apa ketidakmampuan subjek dalam berperilaku asertif.

\section{Presentasi Kasus}

Subjek (Es) merupakan laki-laki berusia 32 tahun, berstatus menikah memiliki 1 orang putra yang berusia sekitar 8 tahun dan tinggal terpisah dari keluarga karena bekerja di daerah lain. Biasanya subjek rutin pulang kerumah satu minggu sekali untuk memberikan gajinya dan bertemu dengan keluarga sejenak. Namun, semua berubah ketika terjadi permasalahan dengan istrinya, dimana subjek merasa istrinya tidak mampu mengatur keuangan, berhutang kepada koperasi, uang selalu habis dan kurang tiap minggunya. Subjek tidak mengutarakan langsung dengan istri perasaan dan pemikirannya, malah memilih untuk pergi bekerja dan tidak pulang kerumah hampir 1 tahun. Subjek hanya pulang sebentar untuk memberikan uang kemudian pergi lagi bekerja. Kejadian ini membuat subjek akhirnya menemukan seorang wanita yang membuatnya nyaman, dan menjalin hubungan dengan wanita tersebut. Wanita yang dikencani merupakan anak temannya bekerja (18 tahun), mereka sudah saling mengetahui latar belakang keluarga masing-masing, dan subjek sempat berpikiran untuk melanjutkan ke hubungan yang lebih serius dengan wanita itu. 
Berdasarkan hasil tes yang dilakukan, diketahui subjek memiliki kategori intelektual rata-rata dengan permasalahan adanya dorongan impulsif yang tidak stabil, pemalu, tertutup, kurang tegas, mudah terpengaruh, dan memiliki hambatan dengan lingkungan sekitarnya. Subjek mendapatkan skor $10 \%$ dalam skala perilaku asertif yang menunjukkan bahwa perilaku asertif untuk mengungkapkan ide, pikiran, maupun perasaan terhadap lingkungan tergolong rendah. Kondisi ini sudah sejak lama terjadi pada subjek, setelah ayahnya meninggal dan ibunya bekerja sendirian membuat subjek merasa kasihan dan takut membebani kelurganya atau siapapun yang disekelilingnya ketika perasaan dan pemikirannya diungkapkannya.

Subjek mengaku pernah berada disituasi dimana dirinya mencoba untuk mengungkapkan perasaan dan pendapatnya kepada bawahannya, karena statusnya sebagai pengawas mengharuskannya bersikap seperti itu. Namun, yang bawahannya terlihat tidak senang dan menjauhi dirinya. Hal ini membuat subjek percaya bahwa Ia tidak perlu mengungkapkan pendapatnya yang akan menyakiti perasaan orang lain. Skinner mengungkapkan bahwa jika suatu tingkah laku diberikan penguatan termasuk pembentukan, pemeliharaan, atau penghapusan perilaku merupakan bentuk dari pengkondisian tingkah laku individu (Corey, 2003). Hal yang terjadi dengan subjek merupakan penguatan dimana tingkah laku yang dimunculkannya mendapatkan respon negatif yang justru memperkuat perilaku tersebut. Penguatan negatif tersebut menjadikan dirinya semakin yakin bahwa dirinya tidak perlu mengutarakan pikiran dan perasaannya jika hanya menyakiti orang lain saja.

Antecedent (A) adalah suatu keadaan dimana stimulus yang diberikan pertama kali sehingga memunculkan perilaku, pemikiran, maupun perasaan; Behavior (B) adalah reaksi dari keadaan yang terjadi; dan akhirnya membentuk Consequence $(\mathrm{C})$ yang merupakan bentuk dari kenyamanan untuk mempertahankan perilaku tersebut (Corey, 2003). Kondisi yang terjadi pada Es dapat terlihat dimana ketika menegur teman atau bawahan yang melakukan kesalahan, istri yang tidak mampu mengatur keuangan (A) membuatnya dijauhi sebagai bentuk penguatan tidak asertif, akhirnya Es tidak ingin lagi mengutarakan pendapatnya terhadap orang lain dan memendam semua ide dan perasaannya (B) sehingga dirinya tidak perlu merasa tidak enak terhadap orang lain dan (C). Kejadian terakhir yang dialami, Es masuk penjara dengan tuduhan membawa kabur anak gadis teman kerjanya yang merupakan kekasihnya dan melakukan pencabulan dikarenakan usia anak tersebut masih 18 tahun. Padahal temannya sendiri sudah mengetahui hubungan itu dan membiarkan mereka berhubungan. Es juga sudah menjelaskan kronologi keadaan kepada temannya tersebut, tetapi tidak tegasnya subjek terhadap situasi tersebut yang tidak diperbuatnya, akhirnya dirinya bersedia dimasukan ke penjara karena tidak mampu membawa gadis itu kembali kepada orangtuanya.

Penguatan dari lingkungan terhadap sikap tidak asertif yang selama ini didapatkan membuatnya mempertahankan perilaku tidak asertif untuk menghindari konsekuensi social berupa dijauhi orang-orang disekitar lingkungannya.

\section{Diagnosis dan Prognosis}

\section{Diagnosis}

Berdasarkan uraian kasus yang sebelumnya telah dijelaskan melalui hasil asesmen dan rujukan pada Diagnostic and Statistical Manual of Mental Disorder fifth edition (DSM - V) (APA 2013), maka dapat ditegakkan diagnosis bahwa subjek memenuhi kriteria other personal risk factors (V15.89) (Z918.89). Faktor risiko yang dimaksud adalah ketidakmampuan untuk berperilaku asertif di lingkungan sosialnya.

\section{Prognosis}

Prognosis baik/positive karena adanya keinginan subjek untuk menyudahi situasi selama ini dan ingin menjadi orangtua yang lebih bertanggung jawab. 


\section{Intervensi}

Intervensi menggunakan tekhnik pelatihan asertif. Pelatihan asertif atau disebut juga modifikasi perilaku merupakan sebuah strategi yang menggunakan prinsip-prinsip analisis behavioral untuk mengubah atau mengontrol perilaku diri sendiri (Martin \& Pear, 2015). Terapi ini diberikan untuk membantu mengatasi permasalahan individu yang tidak mampu mengungkapkan kemarahan atau perasaan tersinggung; menunjukkan kesopanan berlebih; sulit mengatakan "tidak"; sulit mengungkapkan afeksi dan respon positif lainnya; serta merasa tidak punya hak mengutarakan pemikirannya (Corey, 2003).

Pelatihan asertif sesuai diberikan kepada subjek karena ketidakmampuannya untuk mengutarakan yang dipikirkan dan dirasakannya sehingga mengakibatkannya mengalami kesusahan sendiri dan merasa bertanggung jawab untuk permasalahan yang telah terjadi (Novalia \& Dayakisni, Tri, 2013). Terlebih ketika hal itu terjadi dilingkungan pertemanan maupun kehidupannya sehari-hari (Ramdhani, 2015; Hartati., Dimyati., Herdi., 2017).

Terapi ini menekankan pada permainan peran. Tugas terapis untuk memberikan bimbingan dengan memperlihatkan bagaimana dan kapan waktunya subjek harus menyikapi suatu keadaan (Corey, 2003). Stuart dan Laraia (2005), menggambarkan bahwa perilaku asertif dapat membuat seseorang merasa nyaman ketika menyatakan perasaannya dan berkesan memiliki kekuatan namun tidak bersifat mengancam (Suhariyanti \& Pinilih, 2014). Selanjutnya, prosedur pelatihan asertif diterapkan pada subjek melalui 5 sesi yang dilakukan seminggu dua kali dengan waktu 60 menit pada setiap sesinya.

\section{Sesi 1 : Identifikasi masalah}

Menganalisis permasalahan subjek secara komprehensif yang meliputi situasi-situasi umum dan khusus di lingkungan yang menimbulkan kecemasan, pola respon yang ditunjukkan, faktor-faktor yang mempengaruhi, tingkat kecemasan yang dihadapi, motivasi untuk mengatasi masalahnya, serta sistem dukungan.

Pada sesi ini, subjek mengalami kebingungan terhadap permasalahan yang biasanya dihadapinya. Subjek masih merasa ragu-ragu untuk mengungkapkannya karena terbiasa untuk tidak mengemukakan pemikirannya pada orang lain. Sehingga, subjek membutuhkan bantuan terapis untuk memberikan contoh dan melakukan probing kepada subjek kemudian menuliskan perilaku setiap perilaku tidak asertivenya.

\section{Sesi 2: Spesifikasi masalah dan penetapan tujuan}

Menetapkan perilaku bermasalah yang akan diintervensi yaitu perilaku subjek yang kurang mampu dalam mengungkapkan pendapat dan perasaannya dengan menghapus respon yang berupa ketegangan dan ketidaktegasan.

Pada sesi ini, subjek masih memiliki kebingungan terhadap semua perilaku yang selama ini dianggap sudah menjadi kebiasaannya tetapi harus diubah. Subjek memilih dua dari beberapa perilaku yang ingin diatasi oleh subjek. Subjek menjelaskan alasan yang membuatnya penting untuk merubah perilakunya tersebut dikarenakan dirinya harus beradaptasi dengan baik dan membentengi diri selama berada di dalam lapas, terutama saat ini subjek mengalami kendala di dalam blok AO.

\section{Sesi 3: Roleplay}

Subjek akan diminta untuk menjelaskan kriteria orang-orang seperti apa yang dihadapinya sehingga membuatnya tidak mampu berlaku asertif dan kemudian akan memainkan perannya sendiri. Tugas terapis disini untuk mulai mengajarkan subjek bagaimana seharusnya bersikap dalam situasi yang sedang dilakukan. 
Pada sesi ini, subjek berulang kali tertawa dan mengatakan tidak mampu untuk memperagakan cara orang-orang berbicara terhadap dirinya. Ketika subjek sudah mulai berhasil memperagakan cara berbicara orang lain, subjek justru mengalami kesulitan memberikan respon ucapan secara spontan dan membuatnya dua kali ingin menyerah dan tidak mau melanjutkan latihan.

Subjek kembali mencoba untuk memperagakan cara berbicara dan merespon orang lain dengan cukup baik setelah beberapa kali percobaan bersama dengan terapis di ruang terbuka. Subjek diminta untuk melakukan latihan secara langsung mengenai apa yang telah di dapatkannya di dalam Blok.

\section{Sesi 4: Evaluasi \& roleplay}

Subjek diminta untuk mengutarakan sudah sejauh apa ia mampu mengatasi situasi yang terjadi di lingkungan sehari-harinya. Kemudian terapis dan subjek akan memainkan peran kembali pada situasi lain yang kurang asertif.

Pada sesi ini subjek menjelaskan perubahan bahwa dirinya sudah mulai berbicara terbuka dengan orang lain mengenai masalahnya. Namun, untuk mulai berbicara apa yang dirasakannya terhadap teman yang sebelumnya dirasakan tidak nyaman masih belum. Sehingga subjek dan terapis kembali lagi melakukan roleplay terhadap situasi yang sama dan juga mengantisipasi situasi baru yang akan dihadapi. Subjek mulai berani mengungkapkan pemikirannya secara terbuka dengan terapis pada saat sesi ini berlangsung.

\section{Sesi 5: Evaluasi dan Terminasi}

Evaluasi kedua setelah implementasi program dengan prosedur yang sama dengan sesi sebelumnya sekaligus pemberian feedback tentang kinerjanya selama implementasi program, mengakhiri program dan memastikan subjek berkomitmen menerapkan program dalam kehidupan sehari-hari terlepas dari intervensi melalui kontrak perilaku.

Pada sesi ini, subjek sudah mampu mengungkapkan pemikiran dan perasaannya yang tidak sesuai dengan lingkungannya. Subjek juga sudah mulai mampu memulai percakapan lebih dahulu dengan orang baru dan menghadapi situasi baru.

Sesi ini berjalan sangat lancar dan diakhiri dengan menutup intervensi yang telah dilakukan sembari subjek diminta untuk mengisi skala dan diberikan saran dari terapis untuk mempertahankan perilaku yang telah muncul.

\section{Hasil dan Pembahasan}

\section{Hasil}

Sebelum intervensi dilakukan dan sesudah intervensi dilaksanakan, terlihat perbedaan yang cukup signifikan terhadap perilaku dan perasaan yang dirasakan oleh subjek. Ketika diberikan kembali rathus asertive scale (RAS), terjadi peningkatan terhadap subjek, dimana subjek mendapatkan point 55\% yang artinya kemampuan asertif subjek meningkat (dari 10\%). Subjek tidak hanya mampu untuk mengutarakan perasaan dan pikirannya, tetapi juga mampu menata ulang bahasa dan pemikirannya untuk mengatasi kecemasan ketika mengutarakan pemikirannya.

Pada sesi pertama dalam intervensi, subjek menjelaskan beberapa situasi yang memungkinkan dirinya menjadi tidak asertif. Setelah diidentifikasi lebih jauh, akhirnya subjek dan terapis memutuskan untuk memilih dua permasalahan yang memang pada saat ini sedang dihadapi subjek di dalam blok AO lapas. Subjek diminta untuk menceritakan kronologi situasi yang dialaminya dan mengutarakan perasaannya dan alasan yang menyebabkan situasi tersebut.

Ketika situasi selesai diperagakan subjek, meski dengan keadaan malu-malu, dan mengatakan tidak mampu untuk memperagakan cara orang-orang berbicara terhadap dirinya. Ketika 
subjek sudah mulai berhasil memperagakan cara berbicara orang lain, subjek justru mengalami kesulitan memberikan respon ucapan secara spontan dan membuatnya dua kali ingin menyerah dan tidak mau melanjutkan latihan.

Subjek merasa bahwa dirinya telah melakukan kesalahan kepada temannya di blok sehingga dirinya dijauhi dan merasa tidak nyaman. Subjek merasa sikap tersebut tidak adil baginya karena dirinya selama ini selalu berusaha untuk menjadi ramah dan baik pada semua anggota AO, namun tetap saja dirinya merasa dijauhi oleh salah seorang temannya yang sama-sama 'berlayar' dengannya. Subjek merasa seperti dimanfaatkan oleh temannya, meski begitu subjek ikhlas, tetapi tetap saja teman tersebut masih menjauhinya. Subjek tidak berani bertanya dan mengungkapkan perasaan tidak nyamannya karena takut temannya semakin menghindar dan menjauhinya, karena raut wajah temannya langsung berubah begitu melihat dirinya.

Subjek mendapatkan pandangan baru, dirinya merasa mulai tenang dan proses roleplay dilaksanakan. Selama sesi roleplay terlihat masih ada kecemasan subjek untuk mengungkapkan pemikiran dan perasaannya namun subjek antusias untuk menyelesaikan keadaan tersebut. Setelah roleplay berlangsung, subjek kembali ke blok AO dan melakukan tindakan yang sudah dilatih sebelumnya. Ketika dievaluasi, subjek mengungkapkan bahwa dirinya sudah mulai berbicara terbuka dengan orang lain mengenai masalahnya, namun untuk mulai berbicara apa yang dirasakannya terhadap teman yang sebelumnya dirasakan tidak nyaman masih belum dilakukan karena ternyata respon yang didapatkan dari lingkungan berupa perkataan untuk membiarkan teman tersebut sendiri justru membuatnya mengurungkan niat mengutarakannya.

Subjek dan terapis masuk dalam sesi selanjutnya untuk kembali melakukan roleplay pada situasi yang sama dan juga situasi lain, dimana subjek akan dipindahkan ke blok lain sehingga nantinya subjek tidak mengalami hambatan bersosialisasi dengan orang baru. Selama sesi ini berlangsung, subjek memperlihatkan kemajuan yang cukup mengejutkan. Subjek langsung mengutarakan apa yang dipikirkannya kepada terapis ketika dirinya bertanya dan mendapatkan jawaban yang berbeda dari informasi yang didapatkan sebelumnya, "berarti ibu bohong dong, kemarin katanya bukan jawa".

Segera setelah perilaku tersebut muncul, terapis memberikan penguatan berupa pujian atas keberaniannya dalam mengutarakan pemikirannya, subjek langsung tersenyum dan mengatakan bahwa dirinya sedikit lega ketika berbicara lepas seperti yang sudah dilakukannya. Subjek dan terapis kemudian berlatih kepada situasi yang hampir sama dengan yang barusan terjadi dimana dirinya akan mengutarakan perasaan tidak nyamannya dengan temannya. Setelah sesi berakhir, subjek merasa mampu untuk mengutarakannya hari itu juga kepada temannya karena merasakan kelegaan setelah mencoba diberikan penguatan sebelumnya.

Hasil evaluasi akhir dari intervensi ini pun didapati bahwa subjek merasa lebih lega dan komunikasinya menjadi lebih baik dengan temannya tersebut setelah subjek mengutarakan yang dirasakannya dan mengetahui permasalahan sebenarnya. Subjek juga mengatakan bahwa setelah dirinya dipindahkan ke blok yang baru, subjek sudah mampu menolak ajakan berkumpul disaat dirinya harusnya beribadah dengan penolakan yang lebih baik sehingga teman-temannya mengerti situasi dirinya. Subjek juga mengutarakan bahwa komunikasinya saat ini menjadi lebih baik ketika berhadapan dengan orang baru, dirinya tidak perlu lagi gugup dan takut menyakiti oranglain dengan perkataannya ketika dia mampu berpikir lebih terbuka seperti yang sudah diajarkan sebelumnya. Terapis juga mengingatkan subjek untuk terus meningkatkan kemampuannya dalam mengkomunikasikan perasaannya kepada orang lain.

Ketika dilakukan tindak lanjut (follow up) dengan jarak 3 minggu setelah intervensi dilaksanakan, subjek masih mempertahankan perilaku asertifnya dan menikmati keadaannya saat ini sebagai seorang petugas pramuka di lapas yang berinteraksi langsung dengan banyak orang. Subjek juga mengungkapkan bahwa dirinya sudah mulai berani cerita kepada teman ketika ada perasaan yang mengganjal pada dirinya. 


\section{Pembahasan}

Setelah mengikuti serangkaian pelatihan asertif, subjek sudah mampu untuk meningkatkan perilaku asertifnya dan lebih terbuka kepada oranglain dari sebelumnya. Hal ini diwujudkan dalam perilakunya yang lebih santai dalam berbicara dengan orang baru disaat dirinya ditugaskan sebagai anggota pramuka di Lapas yang langsung berhubungan dengan orang baru/asing. Terapi yang dilakukan berhasil membuatnya menyadari kecemasan yang dirasakan tidak wajar sehingga perilaku menjadi berubah.

Pelatihan asertif sebagai salah satu terapi perubahan perilaku berusaha untuk meningkatkan perilaku yang kurang maupun perilaku yang berlebihan terhadap seseorang secara jujur dan terbuka (Sunardi, 2010). Hasil terapi yang dilakukan subjek mampu untuk mengutarakan pendapat dan perasaannya kepada orang lain tanpa merasa takut menyakiti perasaan orang lain (Rathus, 1986). Pelatihan asertif tidak hanya dipergunakan untuk mengungkapkan pemikirannya, tetapi juga untuk membuat subjek mampu menolak hal yang tidak sesuai dengan dirinya dan mampu berkomunikasi lebih baik lagi kepada siapapun tanpa menyinggung, dan tidak menghargai diri sendiri (Fensterheim \& Baer, 1995). Sesuai dengan penelitian yang dilakukan oleh Novalia \& Tri (2013) bahwa ketika mampu berperilaku asertif, maka akan meminimalkan dampak dari rasa diperdaya dan menjadi korban bullying lingkungan sekitar.

Kemampuan tersebut didapatkan dari proses yang berlangsung selama pelatihan asertif dilaksanakan, dimana subjek akan melakukan roleplay terhadap terapis maupun orang lain yang dibuat dalam setting seperti kenyataannya. Hal ini memungkinkan subjek belajar lebih cepat dan siap dalam menghadapi situasi riil dan mampu menggeneralisir terhadap lingkungannya (Ainiyah, H.R., Priyatama, A.N., \& Arif, T.S, 2017; Kirana, Elita., \& Verauli, Roslina, 2018). Terutama ketika diberikan penguatan seperti pujian akan meningkatkan kemungkinan perilaku tersebut diulang yang merupakan hukum belajar kondisioning yang diungkapkan oleh Skinner (Duckworth, M.P., \& Mercer, V dalam Sunardi, 2010).

Terapi yang dilakukan berhasil atas sikap kooperatif dan kemauan subjek dalam menyelesaikan permasalah yang dihadapinya. Sehingga dengan adanya terapi ini, menyadarkan subjek bahwa dirinya memiliki potensi dan mampu mengubah kebiasaan yang dirasanya tidak bisa diatasinya menjadi teratasi dan akan dibagikan dengan keluarganya dirumah ketika pulang kelak karena dirinya merasa bahwa perilaku seperti ini tidak baik jika dibiarkan terus-menerus. Hal ini didukung oleh penelitian yang dilakukan oleh Wardani (2011) yang menunjukkan bahwa pelatihan asertif mampu meningkatkan kemampuan asertif istri untuk mencegah terjadinya kasus kekerasan dalam rumahtangga (Wardani, Nuniek S, 2011).

\section{Simpulan}

Secara keseluruhan Pelatihan Asertif yang diberikan kepada subjek mampu meningkatkan perilaku asertif subjek. Perubahan terlihat jelas dari raut wajah yang sudah lebih bahagia ketika dirinya mampu mengungkapkan pemikirannya dan mendapatkan respon yang berbeda dari yang diperkirakan subjek. Hal ini membuatnya yakin bahwa ketakutan yang selama ini dipikirkannya akan merepotkan orang lain dan membuat dirinya dijauhi karena ucapannya ternyata salah. Subjek merasa lebih lega ketika mampu mengungkapkan perasaannya dengan cara yang benar dan lebih menerima keadaan akan respon yang diberikan orang lain terhadap dirinya.

Setelah melewati beberapa tahapan proses terapi, diharapkan kepada subjek untuk terus mengembangkan kemampuan asertifnya selama berada di dalam lapas sehingga ketika keluar nanti tidak kembali terjadi permasalahan yang serupa seperti sebelumnya. Subjek juga diharapkan mampu untuk mengajarkan kepada lingkungan sekitar untuk sama berperilaku asertif seperti dirinya setelah merasakan manfaatnya. 


\section{Referensi}

American Psychiatric Association. (2013). Diagnostic and statistial manual (5th ed.) Washington, DC: American Psychiatric Publishing.

Ainiyah, HR., Priyatama, AN., \& Arif, TS. (2017). Pengaruh Pelatihan Asertif untuk Meningkatkan Kematangan Emosi Remaja Kelas X Pondok Pesantren Darul Ulum Jombang. Universitas Sebelas Maret.

Corey, Gerald. (2003). Teori dan Praktek Konseling dan Psikoterapi. Bandung: Refika Aditama.

Fensterheim, H., \& Baer, J. (1995). Jangan Bilang Ya Bila Anda Menyatakan Tidak (Terjemahan). Jakarta: Gunung Jati.

Hartati, Herli., Dimyati, Moch., \& Herdi. (2017). Pengaruh Pelatihan Asertif untuk Meningkatkan Asertivitas Terhadap Penyalahgunaan Narkoba (Single subject research anak didik di lapas anak pria tangerang). Universitas Negeri Jakarta.

Kirana, Elita., \& Verauli, Roslina. (2018). Asertive Behavior Therapy \& Positive Reinforcement untuk Meningkatkan Perilaku Asertif Siswa di Lembaga Bimbingan Belajar Y. Jurnal Muara Ilmu Sosial, Humaniora, dan Seni. Vol. 2, no. 1, April 2018: 386-394.

Martin, G., \& Pear, J. (2015). Modifikasi Perilaku: Makna dan Penerapannya (edisi ke-10). Yogyakarta: Pustaka Pelajar.

Novalia., \& Dayakisni, Tri. (2013). Perilaku Asertif dan Kecenderungan Menjadi Korban Bullying. Jurnal Ilmiah Psikologi Terapan. Vol 01(01). ISSN: 2301-8267.

Ramdhani, Neila. (2015). Pelatihan Ketrampilan Sosial untuk Terapi Kesulitan Bergaul. Gadjah Mada University: Researchgate. 265096910.

Rathus, S. A., \& Nevid. (1986). Adjustment and Growth: The Challanges of Life (2nd ed). New York: CBS College Publishing.

Suhariyanti, E, M. Kep., \& Pinilih, Sambodo Sriadi. (2014). Efektifitas Latihan Perilaku Asertif dalam Mencegah Kekerasan pada Anak. Universitas Muhammadiyah Magelang.

Sunardi. (2010). LATIHAN ASERTIF. PLB FIP UPI.

Wardani, Nuniek. S. (2011). Pengaruh Asertive Training Therapy Terhadap Kemampuan Asertif dan Persepsi Istri Terhadap Suami dengan Resiko Kekerasan dalam Rumah Tangga di Kota Bogor. TESIS. FIK UI. 